\title{
Analytical Hierarchy Process Applied to Pedagogical Method Selection Problems
}

\author{
Hind Chaibate $(\mathbb{D}$, Amine Hadek $(\mathbb{D}$, Souad Ajana $(\mathbb{D}$, and Soumia Bakkali $(\mathbb{D}$ \\ Team of Research in Engineering Education, Engineering Research Laboratory, ENSEM-Hassan II University of Casablanca, \\ Casablanca, Morocco \\ Correspondence should be addressed to Hind Chaibate; hind.chaibate.ensem@gmail.com
}

Received 29 October 2020; Revised 22 December 2020; Accepted 17 February 2021; Published 26 February 2021

Academic Editor: Ahmed Rachid

Copyright $(92021$ Hind Chaibate et al. This is an open access article distributed under the Creative Commons Attribution License, which permits unrestricted use, distribution, and reproduction in any medium, provided the original work is properly cited.

The purpose of this study is to apply multicriteria decision-making (MCDM) methods, namely, analytic hierarchy process (AHP) for selecting the best pedagogical method able to develop the soft skills required by the job market with respect to the preference level assigned by employers to each soft skill. The evaluated pedagogical strategies are experiential pedagogy (EP), project-based learning (PjBL), problem-based learning (PBL), serious games (SG), Harvard case method (HCM), and lecture course (LC). Ten criteria (soft skills) were identified from a previous quantitative content analysis of engineering job ads in Morocco in order to identify the extent to which soft skills are required by employers. These skills include communication, efficiency, adaptability, decision-making, innovation, problem resolution, team working, project management, professional responsibility, and using technology in engineering practice. After pairwise comparisons between all the evaluated alternatives with respect to each criterion, results show that experiential pedagogy is the optimal solution to develop the soft skills demanded by the job market.

\section{Introduction}

Soft skills refer to a set of personal and interpersonal skills that are very necessary for every job success by improving students' employability. In order to stay, competitive schools must develop the soft skills required by the job market using innovative and attractive pedagogical strategies. Choosing the best pedagogical methods able to develop the soft skills with respect to the market requirements is an important challenge faced by Moroccan engineering schools. In this work, this challenge is studied as the multicriteria decisionmaking problem where criteria are the soft skills needed by Moroccan employers which were identified during our previous study; pedagogical strategies involved in engineering education represent the alternatives to be evaluated using AHP method.

This research project is part of the framework of improving the employability of engineers through the promotion of the acquisition of soft skills. In the course of this study, we will highlight the importance of establishing a perpetual collaboration between the professional and academic worlds for any capitalization of needs, feedback, and good practices in the development of sustainable employability skills. The need to train qualified and operational graduates is a shared responsibility between these two stakeholders.

The paper is organized as follows. In Section 2, we present different pedagogical methods that will be evaluated through this study. In Section 3, we present the soft skills required by Moroccan job market as a result of our previous quantitative study. Section 4 shows differences between the MCDM methods and justifies the use of the AHP method. In Section 5, we apply AHP method to choose the optimal pedagogical method enabling us to achieve the study goal.

\section{Pedagogical Methods}

2.1. Interactive Lecture Course. Lecture course (LC) is a teaching activity belonging to the transmissive model of teaching where instructor plays a key role in the learning 
process by teaching oral content to a large group of students. The interactivity of the lecture course involves the student's reaction to the teacher's discourse through discussions or exercises $[1,2]$. The use of this model can be justified when it comes to transmitting new concepts that do not require specific prerequisites. The relevance of lecture courses is often criticized by the fact that they are based on a simple transmission of knowledge whereas engineering or any professional training requires the development of a set of skills required by the job market [3-5].

\subsection{Project-Based Learning (PjBL). Project-based learning} (PjBL) belongs to active pedagogical methods where learning is centered on the student's activity. In this method, the learner develops knowledge and skills by carrying out a concrete team-based production $[6,7]$. The instructor facilitates the learning progress by coaching and supervising teams. This pedagogical strategy enables students to apply the acquired knowledge and skills in practical situations in order to develop and strengthen key employability skills such as teamwork, critical thinking, communication, autonomy, decision-making, and creativity [8-10]. To make a successful project, students must be able to manage a set of factors defining the project, namely, resources, time, quality, and other specifications. In this way, the learner develops the managerial skills required by the professional world. Projectbased learning can be applied according to the phases presented in Figure 1 [10].

The project must be well achievable and dimensioned in relation to the students' capacities by presenting objectives that can be achieved within an acceptable deadline. It must also allow learners to develop the skills and knowledge preestablished by the teacher who plans and defines the project according to the learning objectives. Students must understand the project specifications and plan and implement the action plan independently and under the supervision of the instructor who evaluates results achieved by students in terms of deliverables and acquired skills.

2.3. Problem-Based Learning (PBL). Problem-based learning $(\mathrm{PBL})$ is an active pedagogical method based on the involvement of the learner in the learning process. It begins with a problem situation stimulating learner thinking by working as a team to find possible solutions to the problem. Teacher facilitates learning by choosing or designing the problem situation from professional context that is likely to develop the targeted skills and abilities. It also guides the problem-solving approach adopted by students [8]. After reviewing the literature, the PBL generally includes the phases described in Figure $2[8,11]$.

PBL enables learners to develop a set of skills and abilities such as autonomy, communication, teamwork, analytical thinking, decision-making, creativity, project management, and entrepreneurship $[8,11]$. PBL and PjBL are two pedagogical methods that are similar in that they are both carried out within the context of a project. However, instructors must necessarily distinguish between these two

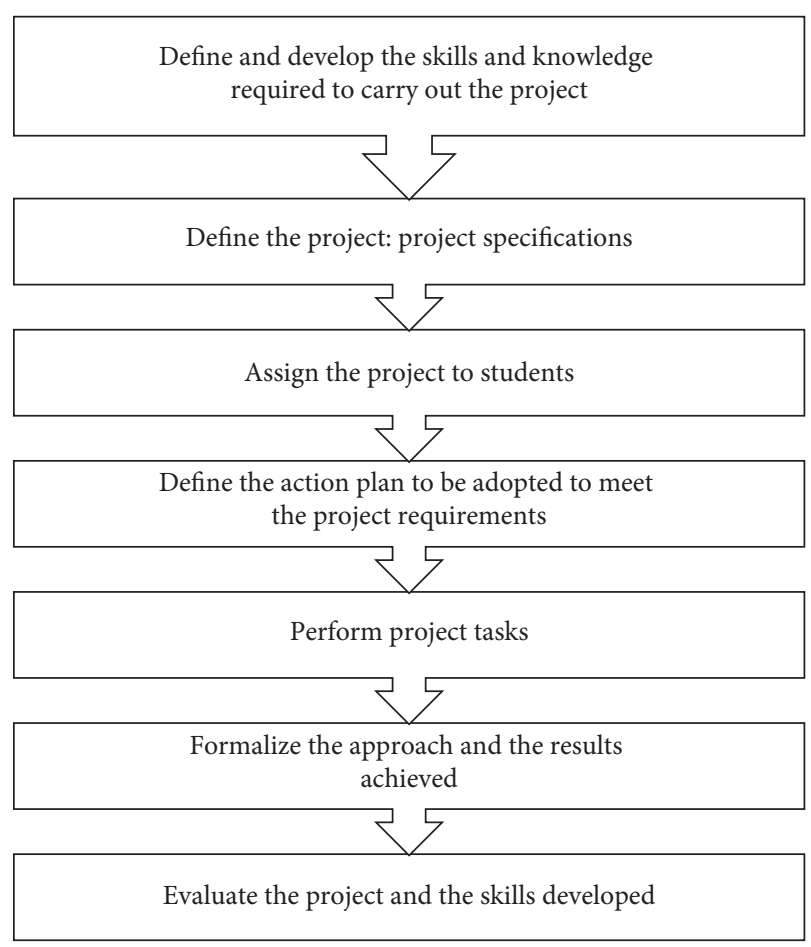

Figure 1: Implementation phases of project-based learning.

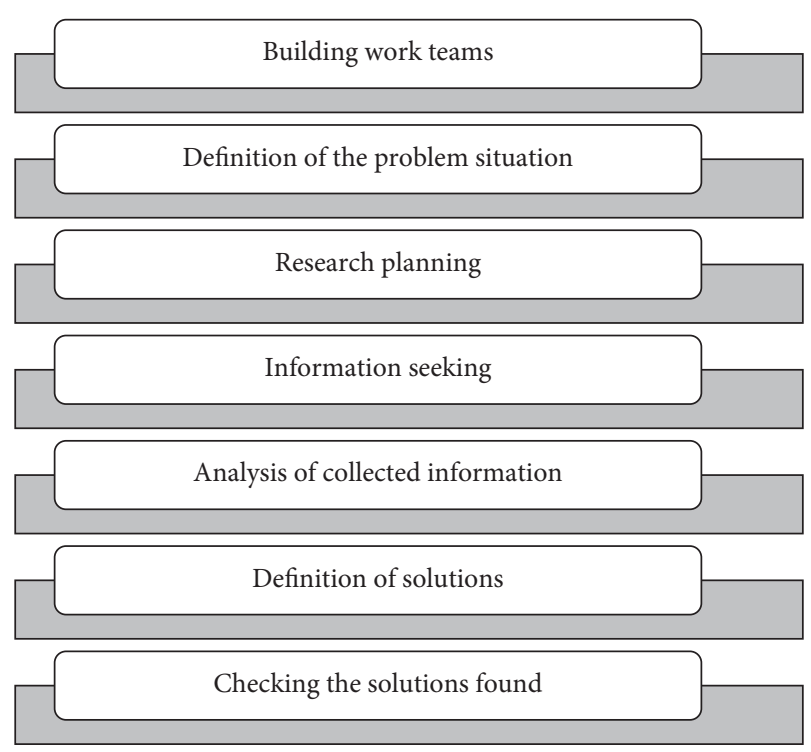

Figure 2: Phases of PBL.

different strategies. Table 1 describes some points of divergence between $\mathrm{PjBL}$ and $\mathrm{PBL}[6,8]$.

2.4. Harvard Case Method. Harvard case method (HCM), developed at Harvard University, is an active pedagogical strategy aimed at confronting students in small groups with experienced professional situations in order to understand the real use of the concepts studied in the course. It is based mainly on the interaction between the instructor and the 
TABLe 1: Points of divergence between PBL and PjBL.

\begin{tabular}{|c|c|c|}
\hline & Problem-based learning (PBL) & Project-based learning (PjBL) \\
\hline Project duration & One to a few weeks & Several months \\
\hline Team & Mono-disciplinary & Multidisciplinary \\
\hline Evaluation criteria & Skills and knowledge acquisition & $\begin{array}{l}\text { (i) Realization of a deliverable } \\
\text { (ii) Skills and knowledge development }\end{array}$ \\
\hline Team working & $\begin{array}{l}\text { (i) Alternate collective and individual work } \\
\text { (ii) All students perform the same tasks }\end{array}$ & $\begin{array}{l}\text { (i) Dominant teamwork } \\
\text { (ii) The students carry out different and complementary missions }\end{array}$ \\
\hline $\begin{array}{l}\text { Learning } \\
\text { outcomes }\end{array}$ & $\begin{array}{l}\text { All students in the team must develop the same } \\
\text { skills }\end{array}$ & $\begin{array}{l}\text { Student develops the competence related to the task assigned to } \\
\text { him/her }\end{array}$ \\
\hline
\end{tabular}

student by assigning them different roles presented in Table $2[8,12,13]$.

The case method allows the student to face a concrete decision-making situation supervised by the teacher in order to develop the skills required to train tomorrow's decisionmakers such as analytical and synthetic thinking, decisionmaking, communication, and teamwork. This method replaces traditional application exercises with concrete case studies to motivate students to become more involved in the learning situation.

2.5. Experiential Pedagogy. Experiential pedagogy (EP) is a pedagogical method that promotes learning through participation in professional activities. The experience allows students to adapt their knowledge and abilities to the context they have encountered [14]. It also allows students to develop skills that are widely required by employers such as autonomy, self-confidence, initiative, problem solving, professional involvement, and social responsibility [15].

Experiential learning, according to Kolb, is based on two principles: the first requires that knowledge must be constructed from lived experiences; the second uses new experience to validate constructed knowledge. For him, this type of learning can only be accomplished if it is composed of four essential phases that constitute Kolb's learning cycle presented in Figure 3 [16, 17].

For example, in engineering education, students must complete their academic training with internships in companies where they benefit from academic supervision provided by a school teacher and industrial supervision provided by a field professional. The internship, as well as experience in the job market, improves the employability of future graduates by enabling them to develop the skills necessary for them to be operational in their workplace, namely, communication, social responsibility, professional commitment, and managerial attitudes.

2.6. Serious Games. Serious games (SG) are not designed for a main purpose to entertain, but instead, they are used to achieve particular learning objectives in many fields such as education, health care, manufacturing, planning, engineering, security, and crisis management. SG can be used to promote a set of skills including initiative, decision-making, adaptability, creativity, problem solving skills, communication, team working, leadership, professional ethics, and social responsibility [18-20]. They are largely used in education due to their ability to use latest modelling and simulation technologies to engage students in an environment close to the realistic experience where they will develop their skills and abilities [21]. Entertainment and learning are coupled with SG according to the following hypotheses [22]:

(i) Facilitator hypothesis: where more learning performance requires more entertainment

(ii) Distraction hypothesis: when entertainment increases, learning performances decrease

(iii) Moderate entertainment hypothesis: in which entertainment must be used moderately. If it exceeds a certain level, learning performance can decrease

Serious games are classified into three major categories presented as follows:

(i) Learning games: they aim to increase knowledge and developing skills by exposing students to a learning situation which may or may not be close to the real practice

(ii) Persuasive games: they are used to convey informative, persuasive, and subjective message and are widely adopted in particular fields including advertisements, marketing, and politics

(iii) Simulation games: they enable learners to develop particular skills and abilities by exposing them to realistic simulation situations promoting skills practice

\section{Identification of the Soft Skills Required by Moroccan Job Market}

Soft skills (SS) refer to a set of personal, interpersonal, managerial, social, and ethical skills that enable engineers to improve their employability. We have previously conducted a study aimed at identifying the soft skills required in Moroccan engineering education. For this reason, we have analyzed engineering job ads in different fields. This study has enabled us to determine the importance given by employers to the soft skills presented in Table $3[23,24]$.

Soft skills can be developed simultaneously by the pedagogical method presented above. In order to stay competitive, engineering schools must take advantage of the contribution of decision-making methods in order to choose teaching strategies enabling students to develop the soft skills according to the market requirements. 
TABLe 2: Different roles of instructor and learner.

\begin{tabular}{ll}
\hline Instructor's role & Learner's role \\
\hline & (i) Analyze the case study \\
$\begin{array}{ll}\text { (i) Define the case according to the learning objectives } & \text { (ii) Propose a diagnosis (interpretation and justification of the } \\
\text { (ii) Study in depth the case to be presented to students by seeking } & \text { observed phenomena) } \\
\text { possible solutions } & \text { (iii) Define a plan of possible actions or decisions } \\
\text { (iii) Facilitate, guide, and monitor the progress of the case suggested } & \text { (iv) Choose a decision and justify it } \\
\text { to the students } & \text { (v) Discuss the decision with colleagues and the teacher } \\
& \text { (vi) Generate principles and conclusions }\end{array}$
\end{tabular}

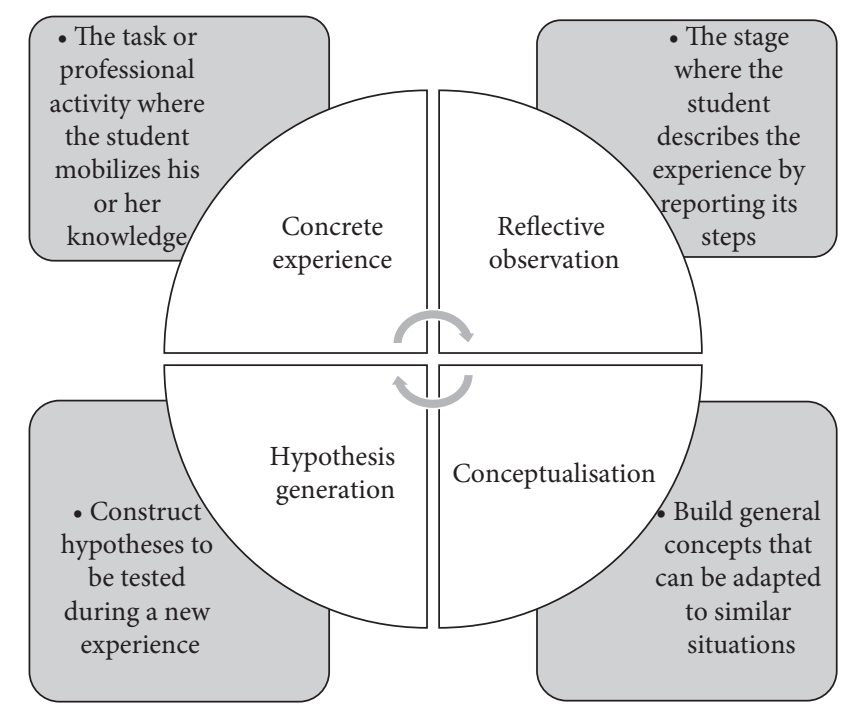

FIgURe 3: Kolb's learning cycle.

TABle 3: Soft skills required by Moroccan job market.

\begin{tabular}{lc}
\hline Soft skills & Frequencies (\%) \\
\hline SS1. Communication (French, English, negotiation) & 84.0 \\
SS2. Organization, rigour, and efficiency & 60.1 \\
SS3. Using technology in engineering practice & 52.8 \\
SS4. Adaptability, initiative, and reactivity & 52.1 \\
SS5. Professional responsibility & 44.8 \\
SS6. Autonomy and decision-making & 39.3 \\
SS7. Project management & 38.7 \\
SS8. Team working & 37.4 \\
SS9. Innovation & 36.2 \\
SS10. Problem resolution (analyze, synthesis) & 30.1 \\
\hline
\end{tabular}

The improvement of Moroccan engineers requires a real collaboration between these two stakeholders:

(i) Academic staff: through their expertise in the field of engineering education. In our study, we involved academics to compare pedagogical methods on the basis of their ability to evaluate and compare different learning and teaching strategies.

(ii) Professionals in the labor market: through their feedback on the professional insertion of Moroccan engineers and their visibility on the skills required by employers. In our study, the use of professionals' feedback has enabled us to determine which soft skills are in high demand and which are in low demand.

While examining the literature, in relation to Moroccan engineers' employability, we found that there is a lack of studies that focus on collaboration between schools and industry in the development of teaching and follow-up program. Existing studies have a one-dimensional aspect, whether they work on the training aspect within the school or they are limited to the professional context. The interest of using multicriteria decision-making method in our study is 
justified by the willingness to take into account this considerable collaboration between academics and professionals in the job market.

\section{Multicriteria Decision-Making (MCDM) Methods}

In a multicriteria decision-making (MCDM) situation, decision-makers are faced with a complex problem with multiple criteria where they should choose the optimal solution using specific MCDM method according to the steps presented in Figure $4[25,26]$.

The problem must be clearly defined in order to choose the best MCDM method. Alternatives represent the possible solutions to the problem while respecting the identified goal. They are described and evaluated according to specific criteria. Decision-makers must apply a suitable MCDM method in order to achieve the optimal solution.

MCDM methods are widely applied in many fields such as business, government, manufacturing, education, research, and medicines. While examining the literature, a variety of decision-making methods can be found, each having its advantages and limitations [27-31]. The following are some of the widely used MCDM methods which will be briefly presented and compared in Table 4 .

When compared to other MCDM methods (Table 4), AHP is characterized by its easiness, flexibility, and ability to simplify multicriteria and multialternative problem into a hierarchical structure. It also helps decision-makers to compare alternatives using pairwise comparison with respect to each criterion while checking judgment consistency using particular indicators. On the other hand, AHP presents two kinds of limitations:

(i) Ranking requires deep knowledge of the object to be judged: in our study, ranking is made on the basis of both academic and professional points of view; both of them have deep knowledge of engineering soft skills

(ii) Important number of pairwise comparison process: in our study, pairwise comparisons present points of intersection and communication between academics and professionals which will encourage the sharing of good practice

As a result, the disadvantages presented by the AHP method do not strongly affect our decision problem.

\section{Previous Studies: AHP Use in Different Fields}

A review of the literature shows that the AHP method has several uses in different multicriteria decision-making situations; Table 5 presents some of these studies.

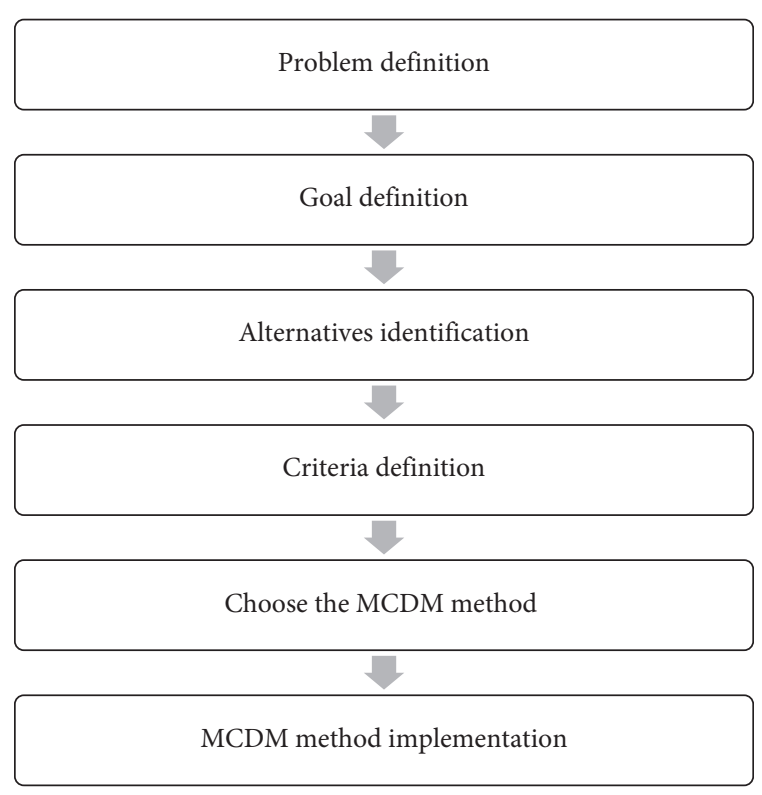

Figure 4: Steps of MCDM process.

\section{Analytic Hierarchy Process (AHP) Applied to Learning Strategy Selection Problems}

6.1. Decision-Makers. In order to carry out this study, we have constructed a focus group of academics (professors, heads of departments), researchers, and professionals (experts (in charge of professional skills development)). This decision problem concerns different stakeholders of the engineering school. For this reason, we have chosen a multidisciplinary team enabling us to make objective and reliable judgments.

6.2. Analytic Hierarchy Process (AHP) Steps. Analytic hierarchy process (AHP), developed by Prof. Thomas L. Saaty, is a multicriteria decision-making method that helps decompose any complex problem into a structured hierarchy of the problem goal, criteria, and alternatives to help decisionmakers choose the optimal solution that best suits the problem's parameters [35]. The AHP can be applied according to the following steps presented in Figure 5.

All the steps presented in Figure 5 will be sufficiently presented in the following sections.

6.3. Setup of the Hierarchical Structure. In order to simplify the problem, AHP method suggests starting with setting a hierarchical structure composed of the problem goal (1st level), criteria (2nd level), and the alternatives to be evaluated (3rd level) as shown in Figure $6[36,37]$.

The goal of our study is to select a suitable learning strategy able to best develop all the soft skills representing criteria which are prioritized by the employers through a quantitative content analysis of the market job ads. 
TABLE 4: Advantages and limitations of MCDM methods.

\begin{tabular}{|c|c|c|}
\hline MCDM methods & Advantages & Limitations \\
\hline $\begin{array}{l}\text { Elimination and choice translating } \\
\text { reality (ELECTRE) }\end{array}$ & $\begin{array}{l}\text { (i) Can be adapted to qualitative and } \\
\text { quantitative criteria } \\
\text { (ii) It is applied to choosing, ranking, and } \\
\text { sorting decision problems }\end{array}$ & $\begin{array}{l}\text { (i) It is time consuming } \\
\text { (ii) Its process is difficult to be understood by the } \\
\text { decision-maker }\end{array}$ \\
\hline Grey theory & It has the ability to deal with missing data & $\begin{array}{l}\text { (i) It does not give the best solution but helps to } \\
\text { find a good solution }\end{array}$ \\
\hline Analytic hierarchy process (AHP) & $\begin{array}{l}\text { (i) Can be adapted to qualitative and } \\
\text { quantitative criteria } \\
\text { (ii) Easy and flexible } \\
\text { (iii) Complex multicriteria, multialternative } \\
\text { problem is simplified into a hierarchical } \\
\text { structure } \\
\text { (iv) Pairwise comparison of different } \\
\text { alternatives with respect to different criteria } \\
\text { (v) It enables checking inconsistencies to } \\
\text { avoid bias in decision-making }\end{array}$ & $\begin{array}{l}\text { (i) Important number of pairwise comparisons } \\
\text { (ii) Ranking requires deep knowledge about the } \\
\text { object to be judged }\end{array}$ \\
\hline $\begin{array}{l}\text { Technique of order preference by } \\
\text { similarity of ideal solution (TOPSIS) }\end{array}$ & $\begin{array}{l}\text { (i) It is best on the fact that optimal solution } \\
\text { must have the shortest geometric distance } \\
\text { from the ideal solution } \\
\text { (ii) Can be adapted to qualitative and } \\
\text { quantitative data }\end{array}$ & $\begin{array}{l}\text { (i) Does not take into account uncertainty } \\
\text { (ii) Can provide unreliable solutions }\end{array}$ \\
\hline $\begin{array}{l}\text { preference ranking organization } \\
\text { methods for enrichment evaluation } \\
\text { (PROMETHEE) }\end{array}$ & $\begin{array}{l}\text { (i) It can be applied to qualitative and } \\
\text { quantitative data } \\
\text { (ii) It is used in complex problems where a } \\
\text { group of decision-makers are engaged }\end{array}$ & $\begin{array}{l}\text { It does not simplify the problem by giving a } \\
\text { hierarchical structure; as a result, decision process } \\
\text { becomes more difficult when many criteria and } \\
\text { alternatives are involved }\end{array}$ \\
\hline
\end{tabular}

TABLE 5: Examples of AHP uses in different multicriteria decision-making situations.

\begin{tabular}{ll}
\hline Studies & Importance of the study \\
& The importance of this study lies in using the AHP method to investigate mechanical and morphological \\
properties of acrylonitrile butadiene styrene nanocomposite foams. The study results show the following: \\
(i) Holding pressure is the most effective parameter on cell size, cell density, and relative density with the \\
contribution of $90 \%, 70 \%$, and $41 \%$, respectively \\
(ii) Nanoclay content is the most effective parameter on the tensile strength and hardness with the \\
contribution of $79 \%$ and $89 \%$, respectively \\
The study develops an algorithm by using the AHP method to evaluate the functionality of software. The \\
authors carried out several pairwise comparisons in order to determine which of these criteria, correctness, \\
compatibility, and accuracy, is more important in measuring software performance \\
The paper aims to present the application the AHP method for project selecting in the context sustainable \\
development using the following criteria: \\
(i) Production \\
(33] \\
(ii) Return on investment \\
(iii) Allocation of hours for the production of the machine \\
(iv) Usability of an empty production area \\
(v) Number of employees-direct staff \\
(vi) Number of special positions-indirect staff \\
(vii) Defect rate with less impact on the environment (\%) \\
(viii) Defect rate leading to the production of hazardous waste mercury (kg) \\
(ix) Electricity consumption (kW)
\end{tabular}

6.4. Criteria Comparison. In order to set up the priority vector for criteria, AHP suggests an $n \times n$ pairwise comparison matrix $A[36,37]$.

$$
A=\left(\begin{array}{ccc}
a_{11} & \cdots & a_{1 n} \\
\vdots & \ddots & \vdots \\
a_{n 1} & \cdots & a_{n n}
\end{array}\right)=\left(a_{i j}\right)_{i j}
$$

where $a_{i j}$ is the element of row $i$ column $j$ of the matrix, $n$ is the number the evaluated criteria, $a_{j i}=\left(1 / a_{i j}\right)$, and $a_{i i}=a_{j j}=1 . a_{i j}$ represents the importance of the criterion $i$ when compared to the criterion $\mathrm{j}$ :

(i) If $a_{i j}>1$, the criterion $i$ is more important than the criterion $j$ 


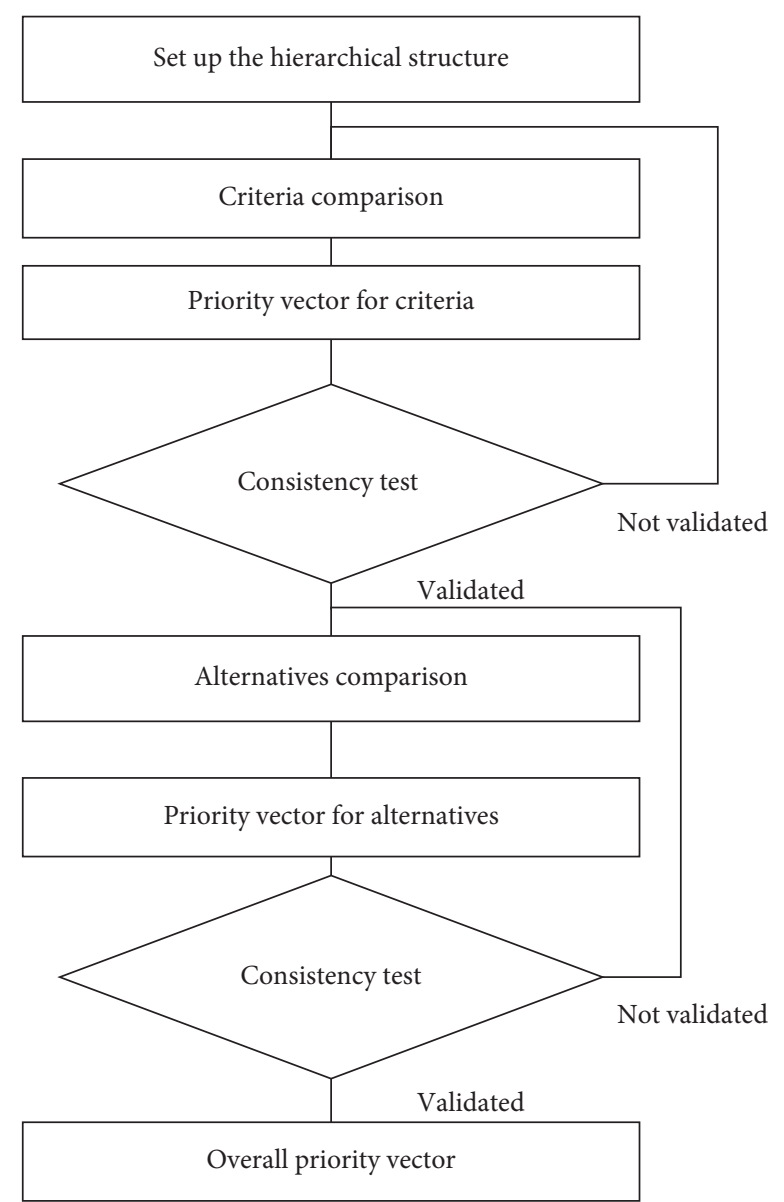

Figure 5: Analytic hierarchy process (AHP) steps.

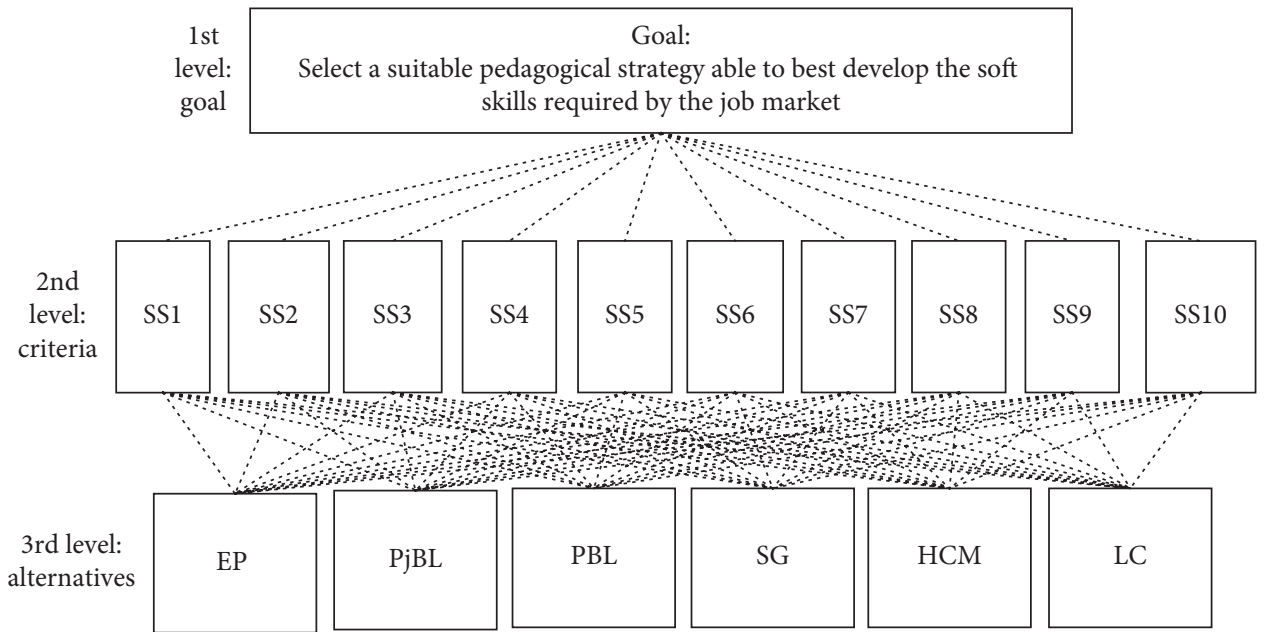

FIgURE 6: Hierarchical structure of the decision problem. 
(ii) If $a_{i j}<1$, the criterion $i$ is less important than the criterion $j$

(iii) If $a_{i j}=1$, the criteria $i$ and $j$ have the same importance

In AHP, the relative importance between two criteria is evaluated on the basis of a numerical scale ranging from 1 to 9, as described in Table 6.

Criteria comparison and AHP scale assignment have been performed by the focus group on the basis of the job market requirements shown in Table 3.

6.5. Priority Vector for Criteria. After building the matrix A, the priority vector of criteria is calculated using the following steps $[38,39]$ :

(1) Normalized pairwise comparison matrix $A_{\text {norm: }}$ it is a matrix where the sum of the entries of each column is equal to 1 ; i.e., $\sum_{i=1}^{n} \overline{a_{i j}}=1$.

$$
A_{\text {norm }}=\left(\begin{array}{ccc}
\overline{a_{11}} & \cdots & \overline{a_{1 n}} \\
\vdots & \ddots & \vdots \\
\overline{a_{n 1}} & \cdots & \overline{a_{n n}}
\end{array}\right)=\left(\overline{a_{i j}}\right)_{i j}
$$

The matrix $A_{\text {norm }}$ entries $\overline{a_{i j}}$ are calculated using the entries $a_{i j}$ of the matrix $A$ using

$$
\overline{a_{i j}}=\frac{a_{i j}}{\sum_{k=1}^{n} a_{k j}} .
$$

(2) The priority vector of criteria: it is an $n$-dimensional column vector $P$.

$$
P=\left(\begin{array}{c}
p_{1} \\
\vdots \\
p_{n}
\end{array}\right)
$$

$P$ is achieved by averaging the entries of each row of the matrix $A_{\text {norm }}$ using

$$
p_{i}=\frac{\sum_{k=1}^{n} \overline{a_{i k}}}{n} \text {. }
$$

6.6. Consistency Test. In order to check the consistency of the comparisons made by decision-makers, namely, the matrix A, AHP suggests a technique based on testing the consistency ratio (CR) which is calculated using formula (6) (Lokare, and Jadhav, 2016) [38, 39]:

$$
\mathrm{CR}=\frac{\mathrm{CI}}{\mathrm{RI}}
$$

where CI is calculated using

$$
\mathrm{CI}=\frac{(\lambda-n)}{n-1},
$$

TABLE 6: AHP scale for criteria comparison.

\begin{tabular}{lc}
\hline Scale & Relative importance of factor $i$ compared to factor $j$ \\
\hline 1 & Equally important \\
3 & Moderately more important \\
5 & Strongly more important \\
7 & Very strongly more important \\
9 & Extremely more important \\
$2,4,6,8$ & Intermediate values \\
\hline
\end{tabular}

TABLE 7: RI values according to the number of factors $n$.

\begin{tabular}{lc}
\hline Number of factors $(n)$ & RI \\
\hline 1 & 0.00 \\
2 & 0.00 \\
3 & 0.58 \\
4 & 0.90 \\
5 & 1.21 \\
6 & 1.24 \\
7 & 1.32 \\
8 & 1.41 \\
9 & 1.45 \\
10 & 1.49 \\
\hline
\end{tabular}

where $\lambda$ is calculated using

$$
\lambda=\sum_{i=1}^{n} p_{i} * \sum_{k=1}^{n} a_{k i} .
$$

$\mathrm{RI}$ is a random index changing according the order $n$ of the matrix as shown in Table 7.

(i) If $0 \leq \mathrm{CR} \leq 0.1$, the evaluations made by the decisionmaker are consistent

(ii) If $\mathrm{CR}>0.1$, the judgment made by the decisionmaker is inconsistent; as a result, the evaluations must be revised

The priority vector of criteria with respect to the goal is presented in Table 8 where $\mathrm{CR}=7.3 \% \leq 0.1$ which represents a validated consistency test.

6.7. Alternatives Comparison. After checking the consistency of the matrix of the criteria comparison, an $\mathrm{m} \times \mathrm{m}$ pairwise comparison matrix $B^{k}$ must be built for each of the $n$ criteria $(k=1, \ldots, n)$. In this matrix, alternatives are compared with respect to the criteria; $m$ is the number of alternatives to be evaluated.

$$
B^{k}=\left(\begin{array}{ccc}
b_{11}^{k} & \cdots & b_{1 n}^{k} \\
\vdots & \ddots & \vdots \\
b_{n 1}^{k} & \cdots & b_{n n}^{k}
\end{array}\right)=\left(b_{i j}^{k}\right)_{i j}
$$

where $b_{i j}^{k}$ represents the evaluation of the alternative $i$ compared to the alternative $j$ with respect to the criterion $k$. The entries of this matrix satisfy the following conditions: 
TABLE 8: Pairwise comparison matrix of criteria with respect to goal.

\begin{tabular}{|c|c|c|c|c|c|c|c|c|c|c|c|c|c|}
\hline \multicolumn{14}{|c|}{ Pairwise comparison matrix } \\
\hline & SS1 & SS2 & SS3 & SS4 & SS5 & SS6 & SS7 & SS8 & SS9 & SS10 & & & \\
\hline SS1 & 1 & 5 & 5 & 5 & 7 & 7 & 7 & 7 & 7 & 9 & & & \\
\hline SS2 & $1 / 5$ & 1 & 3 & 3 & 3 & 5 & 5 & 5 & 5 & 5 & & & \\
\hline SS3 & $1 / 5$ & $1 / 3$ & 1 & 1 & 3 & 3 & 3 & 3 & 3 & 5 & & & \\
\hline SS4 & $1 / 5$ & $1 / 3$ & 1 & 1 & 3 & 3 & 3 & 3 & 3 & 5 & & & \\
\hline SS5 & $1 / 7$ & $1 / 3$ & $1 / 3$ & $1 / 3$ & 1 & 3 & 3 & 3 & 3 & 3 & & & \\
\hline SS6 & $1 / 7$ & $1 / 5$ & $1 / 3$ & $1 / 3$ & $1 / 3$ & 1 & 1 & 1 & 1 & 3 & & & \\
\hline SS7 & $1 / 7$ & $1 / 5$ & $1 / 3$ & $1 / 3$ & $1 / 3$ & 1 & 1 & 1 & 1 & 3 & & & \\
\hline SS8 & $1 / 7$ & $1 / 5$ & $1 / 3$ & $1 / 3$ & $1 / 3$ & 1 & 1 & 1 & 1 & 3 & & & \\
\hline SS9 & $1 / 7$ & $1 / 5$ & $1 / 3$ & $1 / 3$ & $1 / 3$ & 1 & 1 & 1 & 1 & 3 & & & \\
\hline SS10 & $1 / 9$ & $1 / 5$ & $1 / 5$ & $1 / 5$ & $1 / 3$ & $1 / 3$ & $1 / 3$ & $1 / 3$ & $1 / 3$ & 1 & & & \\
\hline Sum & 2.43 & 8.00 & 11.87 & 11.87 & 18.67 & 25.33 & 25.33 & 25.33 & 25.33 & 40.00 & & & \\
\hline \multicolumn{11}{|c|}{ Normalized matrix } & & & \\
\hline & SS1 & SS2 & SS3 & SS4 & SS5 & SS6 & SS7 & SS8 & SS9 & SS10 & Sum & Priority vector & Check for consistency \\
\hline SS1 & 0.41 & 0.63 & 0.42 & 0.42 & 0.37 & 0.28 & 0.28 & 0.28 & 0.28 & 0.23 & 3.58 & 0.36 & \multirow{11}{*}{$\begin{array}{c}\lambda=10.97 \\
n=10 \\
\mathrm{RI}=1.49 \\
\mathrm{CR}=7.3 \%\end{array}$} \\
\hline SS2 & 0.08 & 0.13 & 0.25 & 0.25 & 0.16 & 0.20 & 0.20 & 0.20 & 0.20 & 0.13 & 1.79 & 0.18 & \\
\hline SS3 & 0.08 & 0.04 & 0.08 & 0.08 & 0.16 & 0.12 & 0.12 & 0.12 & 0.12 & 0.13 & 1.05 & 0.11 & \\
\hline SS4 & 0.08 & 0.04 & 0.08 & 0.08 & 0.16 & 0.12 & 0.12 & 0.12 & 0.12 & 0.13 & 1.05 & 0.11 & \\
\hline SS5 & 0.06 & 0.04 & 0.03 & 0.03 & 0.05 & 0.12 & 0.12 & 0.12 & 0.12 & 0.08 & 0.76 & 0.08 & \\
\hline SS6 & 0.06 & 0.03 & 0.03 & 0.03 & 0.02 & 0.04 & 0.04 & 0.04 & 0.04 & 0.08 & 0.39 & 0.04 & \\
\hline SS7 & 0.06 & 0.03 & 0.03 & 0.03 & 0.02 & 0.04 & 0.04 & 0.04 & 0.04 & 0.08 & 0.39 & 0.04 & \\
\hline SS8 & 0.06 & 0.03 & 0.03 & 0.03 & 0.02 & 0.04 & 0.04 & 0.04 & 0.04 & 0.08 & 0.39 & 0.04 & \\
\hline SS9 & 0.06 & 0.03 & 0.03 & 0.03 & 0.02 & 0.04 & 0.04 & 0.04 & 0.04 & 0.08 & 0.39 & 0.04 & \\
\hline SS10 & 0.05 & 0.03 & 0.02 & 0.02 & 0.02 & 0.01 & 0.01 & 0.01 & 0.01 & 0.03 & 0.20 & 0.02 & \\
\hline Sum & 1.00 & 1.00 & 1.00 & 1.00 & 1.00 & 1.00 & 1.00 & 1.00 & 1.00 & 1.00 & 10.00 & 1.00 & \\
\hline
\end{tabular}

TABle 9: Pairwise comparison matrix of learning strategies with respect to the criterion "SS1. Communication (French, English, negotiation)."

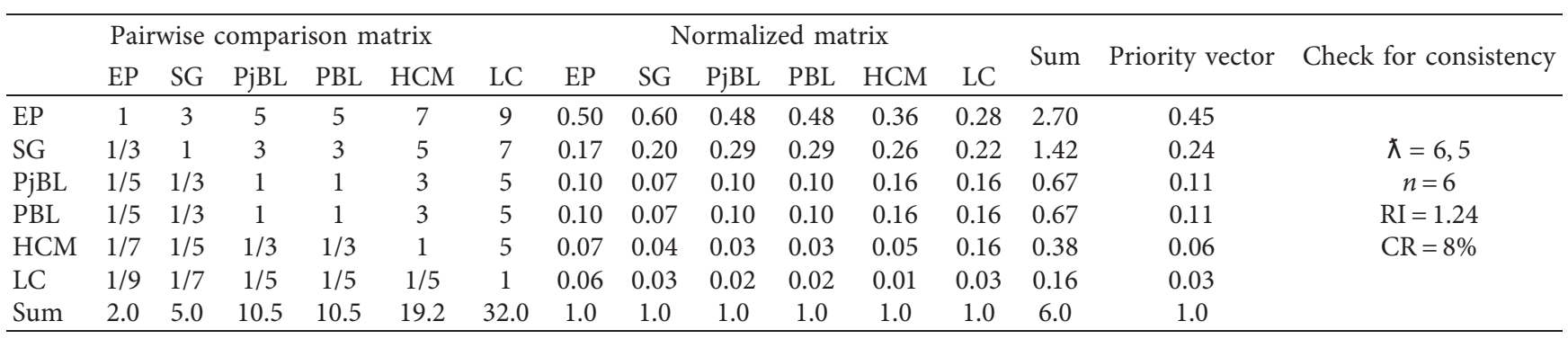

TABLE 10: Pairwise comparison matrix of learning strategies with respect to the Criterion "SS2. Organization, rigour, and efficiency."

\begin{tabular}{|c|c|c|c|c|c|c|c|c|c|c|c|c|c|c|c|}
\hline & \multicolumn{5}{|c|}{ Pairwise comparison matrix } & \multicolumn{7}{|c|}{ Normalized matrix } & \multirow{2}{*}{ Sum } & \multirow{2}{*}{ Priority vector } & \multirow{2}{*}{ Check for consistency } \\
\hline & EP & $\mathrm{PjBL}$ & PBL & SG & $\mathrm{HCM}$ & $\mathrm{LC}$ & EP & $\mathrm{PjBL}$ & PBL & SG & $\mathrm{HCM}$ & $\mathrm{LC}$ & & & \\
\hline$\overline{\mathrm{EP}}$ & 1 & 3 & 4 & 5 & 7 & 9 & 0.52 & 0.61 & 0.46 & 0.37 & 0.34 & 0.28 & 2.58 & 0.43 & \\
\hline $\mathrm{PjBL}$ & $1 / 3$ & 1 & 3 & 4 & 5 & 7 & 0.17 & 0.20 & 0.34 & 0.30 & 0.25 & 0.22 & 1.48 & 0.25 & $\lambda=6,54$ \\
\hline PBL & $1 / 5$ & $1 / 3$ & 1 & 3 & 4 & 7 & 0.10 & 0.07 & 0.11 & 0.22 & 0.20 & 0.22 & 0.92 & 0.15 & $n=6$ \\
\hline SG & $1 / 7$ & $1 / 4$ & $1 / 3$ & 1 & 3 & 5 & 0.07 & 0.05 & 0.04 & 0.07 & 0.15 & 0.16 & 0.54 & 0.09 & $\mathrm{RI}=1.24$ \\
\hline HCM & $1 / 7$ & $1 / 5$ & $1 / 4$ & $1 / 3$ & 1 & 3 & 0.07 & 0.04 & 0.03 & 0.02 & 0.05 & 0.09 & 0.31 & 0.05 & $\mathrm{CR}=8.7 \%$ \\
\hline LC & $1 / 9$ & $1 / 7$ & $1 / 7$ & $1 / 5$ & $1 / 3$ & 1 & 0.06 & 0.03 & 0.02 & 0.01 & 0.02 & 0.03 & 0.17 & 0.03 & \\
\hline Sum & 1.93 & 4.93 & 8.73 & 13.53 & 20.33 & 32.00 & 1.00 & 1.00 & 1.00 & 1.00 & 1.00 & 1.00 & 6.00 & 1.00 & \\
\hline
\end{tabular}

$$
\begin{aligned}
& b_{j i}^{k}=\frac{1}{b_{i j}^{k}}, \\
& b_{i i}^{k}=b_{j j}^{k}=1 .
\end{aligned}
$$

The same scale used to compare criteria (Table 1) is used to evaluate and compare the alternatives with respect to each criterion.

In order to compare the alternatives with respect to each criterion, we repeat the steps described in Sections 6.4-6.6. 
TABLE 11: Pairwise comparison matrix of learning strategies with respect to the Criterion "SS3. Using technology in engineering practice."

\begin{tabular}{|c|c|c|c|c|c|c|c|c|c|c|c|c|c|c|c|}
\hline & \multicolumn{5}{|c|}{ Pairwise comparison matrix } & \multicolumn{7}{|c|}{ Normalized matrix } & \multirow{2}{*}{ Sum } & \multirow{2}{*}{ Priority vector } & \multirow{2}{*}{ Check for consistency } \\
\hline & SG & $\mathrm{EP}$ & $\mathrm{PjBL}$ & PBL & $\mathrm{HCM}$ & $\mathrm{LC}$ & SG & $\mathrm{EP}$ & $\mathrm{PjBL}$ & PBL & $\mathrm{HCM}$ & LC & & & \\
\hline SG & 1 & 3 & 5 & 5 & 5 & 7 & 0.49 & 0.58 & 0.47 & 0.47 & 0.33 & 0.25 & 2.60 & 0.43 & \\
\hline $\mathrm{EP}$ & $1 / 3$ & 1 & 3 & 3 & 3 & 5 & 0.16 & 0.19 & 0.28 & 0.28 & 0.20 & 0.18 & 1.30 & 0.22 & $\lambda=6,63$ \\
\hline $\mathrm{PjBL}$ & $1 / 5$ & $1 / 3$ & 1 & 1 & 3 & 5 & 0.10 & 0.06 & 0.09 & 0.09 & 0.20 & 0.18 & 0.73 & 0.12 & $n=6$ \\
\hline PBL & $1 / 5$ & $1 / 3$ & 1 & 1 & 3 & 5 & 0.10 & 0.06 & 0.09 & 0.09 & 0.20 & 0.18 & 0.73 & 0.12 & $\mathrm{RI}=1.24$ \\
\hline HCM & $1 / 6$ & $1 / 3$ & $1 / 3$ & $1 / 3$ & 1 & 5 & 0.08 & 0.06 & 0.03 & 0.03 & 0.07 & 0.18 & 0.45 & 0.08 & $\mathrm{CR}=10 \%$ \\
\hline LC & $1 / 7$ & $1 / 5$ & $1 / 5$ & $1 / 5$ & $1 / 5$ & 1 & 0.07 & 0.04 & 0.02 & 0.02 & 0.01 & 0.04 & 0.20 & 0.03 & \\
\hline Sum & 2.04 & 5.20 & 10.53 & 10.53 & 15.20 & 28.00 & 1.00 & 1.00 & 1.00 & 1.00 & 1.00 & 1.00 & 6.00 & 1.00 & \\
\hline
\end{tabular}

TABLE 12: Pairwise comparison matrix of learning strategies with respect to the Criterion "SS4. Adaptability, initiative, and reactivity."

\begin{tabular}{|c|c|c|c|c|c|c|c|c|c|c|c|c|c|c|c|}
\hline & \multicolumn{5}{|c|}{ Pairwise comparison matrix } & \multicolumn{7}{|c|}{ Normalized matrix } & \multirow{2}{*}{ Sum } & \multirow{2}{*}{ Priority vector } & \multirow{2}{*}{ Check for consistency } \\
\hline & $\mathrm{EP}$ & $\mathrm{PjBL}$ & PBL & SG & $\mathrm{HCM}$ & LC & EP & PjBL & PBL & SG & $\mathrm{HCM}$ & LC & & & \\
\hline $\mathrm{EP}$ & 1 & 3 & 3 & 4 & 5 & 7 & 0.44 & 0.52 & 0.52 & 0.35 & 0.27 & 0.27 & 2.37 & 0.40 & \\
\hline $\mathrm{PjBL}$ & $1 / 3$ & 1 & 1 & 3 & 4 & 5 & 0.15 & 0.17 & 0.17 & 0.26 & 0.22 & 0.19 & 1.17 & 0.19 & $\lambda=6,54$ \\
\hline PBL & $1 / 3$ & 1 & 1 & 3 & 4 & 5 & 0.15 & 0.17 & 0.17 & 0.26 & 0.22 & 0.19 & 1.17 & 0.19 & $n=6$ \\
\hline SG & $1 / 4$ & $1 / 3$ & $1 / 3$ & 1 & 4 & 5 & 0.11 & 0.06 & 0.06 & 0.09 & 0.22 & 0.19 & 0.72 & 0.12 & $\mathrm{RI}=1.24$ \\
\hline HCM & $1 / 5$ & $1 / 4$ & $1 / 4$ & $1 / 4$ & 1 & 3 & 0.09 & 0.04 & 0.04 & 0.02 & 0.05 & 0.12 & 0.37 & 0.06 & $\mathrm{CR}=9 \%$ \\
\hline $\mathrm{LC}$ & $1 / 7$ & $1 / 5$ & $1 / 5$ & $1 / 5$ & $1 / 3$ & 1 & 0.06 & 0.03 & 0.03 & 0.02 & 0.02 & 0.04 & 0.21 & 0.03 & \\
\hline Sum & 2.26 & 5.78 & 5.78 & 11.45 & 18.33 & 26.00 & 1.00 & 1.00 & 1.00 & 1.00 & 1.00 & 1.00 & 6.00 & 1.00 & \\
\hline
\end{tabular}

TABle 13: Pairwise comparison matrix of learning strategies with respect to the Criterion "SS5. Professional responsibility."

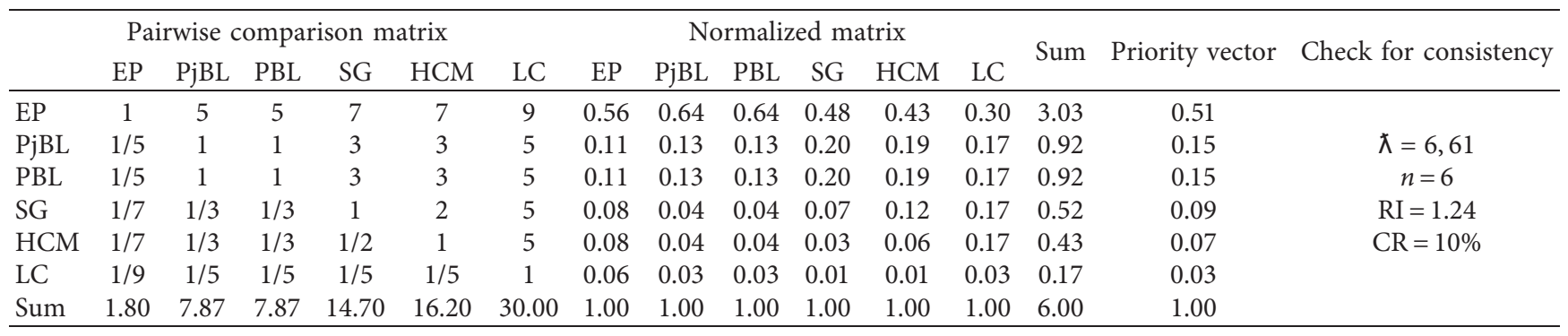

TABLE 14: Pairwise comparison matrix of learning strategies with respect to the Criterion "SS6. Autonomy and decision-making."

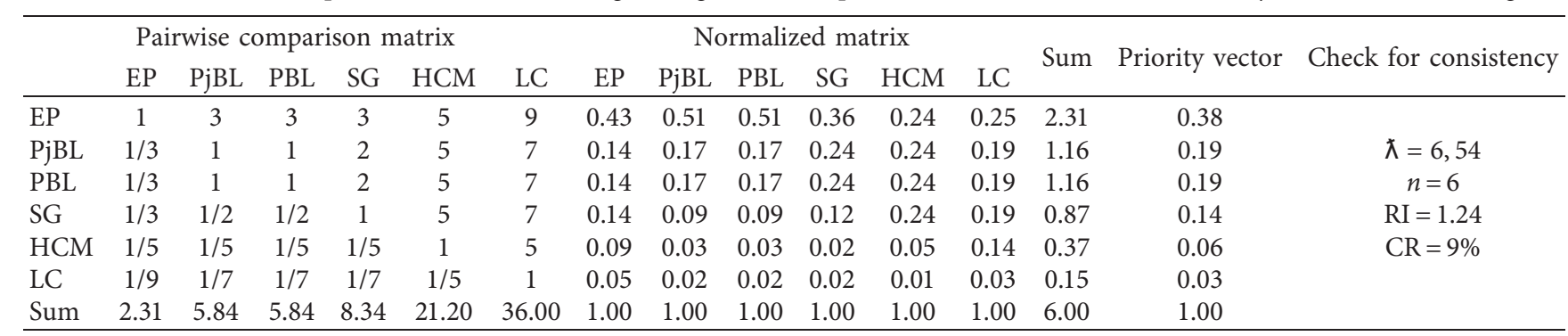

The pairwise comparisons of the alternatives (learning strategies) with respect to the ten criteria (required soft skills) SS1, SS2, SS3, SS4, SS5, SS6, SS7, SS8, SS9, and SS10 are presented in Tables 9-18.

The columns in Table 19 are the priority vectors of the alternatives with respect to each criterion as shown in Tables 9-18. The overall priority is a linear combination of multiplication between alternative priority with respect to each criterion and the criterion's priority (generated in Table 8).
Prioritization of pedagogical strategies using AHP method shows that experiential pedagogy (EP) is the best choice as a learning strategy able to develop engineering soft skills with respect to the market requirements with a highest score of $41 \%$ followed by serious games (SG), project-based learning $(\mathrm{PjBL})$, and problem-based learning $(\mathrm{PBL})$ with closely situated score of $19 \%, 17 \%$, and $15 \%$, respectively. Harvard case method (HCM) and lecture course (LC) have the lowest scores in relation to the goal: $6 \%$ and $3 \%$, respectively. 
TABle 15: Pairwise comparison matrix of learning strategies with respect to the Criterion "SS7. Project management."

\begin{tabular}{|c|c|c|c|c|c|c|c|c|c|c|c|c|c|c|c|}
\hline \multicolumn{7}{|c|}{ Pairwise comparison matrix } & \multicolumn{6}{|c|}{ Normalized matrix } & \multirow{2}{*}{ Sum } & \multirow{2}{*}{ Priority vector } & \multirow{2}{*}{ Check for consistency } \\
\hline & $\mathrm{EP}$ & $\mathrm{PjBL}$ & PBL & SG & $\mathrm{HCM}$ & $\mathrm{LC}$ & EP & $\mathrm{PjBL}$ & PBL & SG & $\mathrm{HCM}$ & LC & & & \\
\hline $\mathrm{EP}$ & 1 & 3 & 3 & 3 & 8 & 9 & 0.45 & 0.59 & 0.45 & 0.26 & 0.33 & 0.30 & 2.37 & 0.40 & \\
\hline $\mathrm{PjBL}$ & $1 / 3$ & 1 & 2 & 4 & 5 & 6 & 0.15 & 0.20 & 0.30 & 0.35 & 0.20 & 0.20 & 1.40 & 0.23 & $\lambda=6,56$ \\
\hline PBL & $1 / 3$ & $1 / 2$ & 1 & 3 & 5 & 6 & 0.15 & 0.10 & 0.15 & 0.26 & 0.20 & 0.20 & 1.06 & 0.18 & $n=6$ \\
\hline SG & $1 / 3$ & $1 / 4$ & $1 / 3$ & 1 & 5 & 6 & 0.15 & 0.05 & 0.05 & 0.09 & 0.20 & 0.20 & 0.74 & 0.12 & $\mathrm{RI}=1.24$ \\
\hline $\mathrm{HCM}$ & $1 / 8$ & $1 / 5$ & $1 / 5$ & $1 / 5$ & 1 & 2 & 0.06 & 0.04 & 0.03 & 0.02 & 0.04 & 0.07 & 0.25 & 0.04 & $\mathrm{CR}=9 \%$ \\
\hline LC & $1 / 9$ & $1 / 6$ & $1 / 6$ & $1 / 6$ & $1 / 2$ & 1 & 0.05 & 0.03 & 0.02 & 0.01 & 0.02 & 0.03 & 0.18 & 0.03 & \\
\hline Sum & 2.24 & 5.12 & 6.70 & 11.37 & 24.50 & 30.00 & 1.00 & 1.00 & 1.00 & 1.00 & 1.00 & 1.00 & 6.00 & 1.00 & \\
\hline
\end{tabular}

TABle 16: Pairwise comparison matrix of learning strategies with respect to the Criterion "SS8. Team working."

\begin{tabular}{|c|c|c|c|c|c|c|c|c|c|c|c|c|c|c|c|}
\hline & \multicolumn{5}{|c|}{ Pairwise comparison matrix } & \multicolumn{7}{|c|}{ Normalized matrix } & \multirow{2}{*}{ Sum } & \multirow{2}{*}{ Priority vector } & \multirow{2}{*}{ Check for consistency } \\
\hline & $\mathrm{EP}$ & PjBL & PBL & SG & $\mathrm{HCM}$ & LC & $\mathrm{EP}$ & $\mathrm{PjBL}$ & PBL & SG & $\mathrm{HCM}$ & LC & & & \\
\hline$\overline{\mathrm{EP}}$ & 1 & 3 & 3 & 4 & 4 & 9 & 0.44 & 0.52 & 0.52 & 0.33 & 0.33 & 0.24 & 2.37 & 0.39 & \\
\hline $\mathrm{PjBL}$ & $1 / 3$ & 1 & 1 & 3 & 3 & 7 & 0.15 & 0.17 & 0.17 & 0.25 & 0.25 & 0.18 & 1.17 & 0.19 & $\lambda=6,42$ \\
\hline PBL & $1 / 3$ & 1 & 1 & 3 & 3 & 7 & 0.15 & 0.17 & 0.17 & 0.25 & 0.25 & 0.18 & 1.17 & 0.19 & $n=6$ \\
\hline SG & $1 / 4$ & $1 / 3$ & $1 / 3$ & 1 & 1 & 7 & 0.11 & 0.06 & 0.06 & 0.08 & 0.08 & 0.18 & 0.57 & 0.10 & $\mathrm{RI}=1.24$ \\
\hline HCM & $1 / 4$ & $1 / 3$ & $1 / 3$ & 1 & 1 & 7 & 0.11 & 0.06 & 0.06 & 0.08 & 0.08 & 0.18 & 0.57 & 0.10 & $\mathrm{CR}=7 \%$ \\
\hline $\mathrm{LC}$ & $1 / 9$ & $1 / 7$ & $1 / 7$ & $1 / 7$ & $1 / 7$ & 1 & 0.05 & 0.02 & 0.02 & 0.01 & 0.01 & 0.03 & 0.15 & 0.02 & \\
\hline Sum & 2.28 & 5.81 & 5.81 & 12.14 & 12.14 & 38.00 & 1.00 & 1.00 & 1.00 & 1.00 & 1.00 & 1.00 & 6.00 & 1.00 & \\
\hline
\end{tabular}

TABle 17: Pairwise comparison matrix of learning strategies with respect to the Criterion "SS9. Innovation."

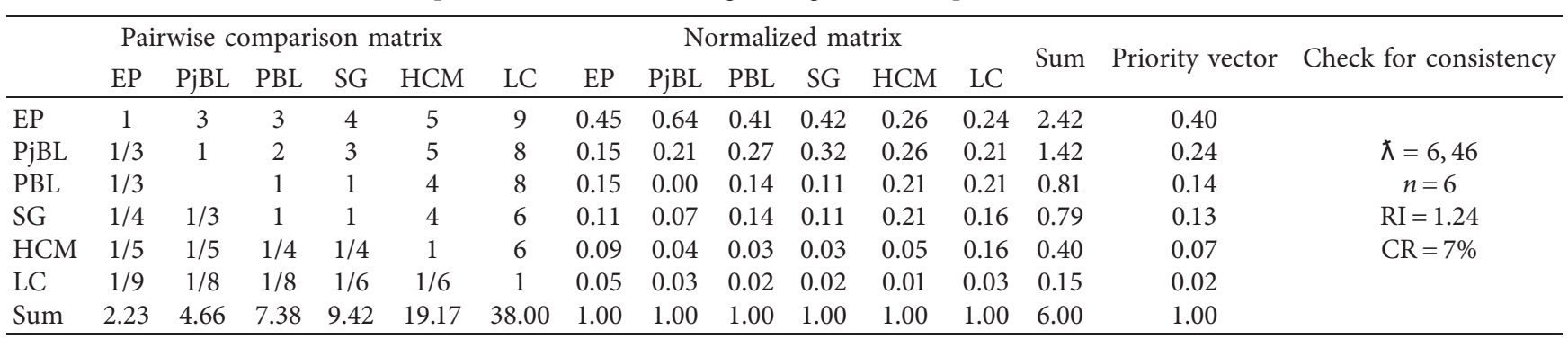

TABLE 18: Pairwise comparison matrix of learning strategies with respect to the Criterion "SS10. Problem resolution (analyze, synthesis)."

\begin{tabular}{|c|c|c|c|c|c|c|c|c|c|c|c|c|c|c|c|}
\hline & \multicolumn{5}{|c|}{ Pairwise comparison matrix } & \multicolumn{7}{|c|}{ Normalized matrix } & \multirow{2}{*}{ Sum } & \multirow{2}{*}{ Priority vector } & \multirow{2}{*}{ Check for consistency } \\
\hline & PBL & EP & $\mathrm{PjBL}$ & SG & $\mathrm{HCM}$ & LC & PBL & EP & $\mathrm{PjBL}$ & SG & $\mathrm{HCM}$ & LC & & & \\
\hline $\mathrm{PBL}$ & 1 & 3 & 3 & 4 & 4 & 9 & 0.46 & 0.62 & 0.39 & 0.28 & 0.28 & 0.26 & 2.29 & 0.38 & \\
\hline $\mathrm{EP}$ & $1 / 3$ & 1 & 3 & 4 & 4 & 7 & 0.15 & 0.21 & 0.39 & 0.28 & 0.28 & 0.21 & 1.52 & 0.25 & $\lambda=6,58$ \\
\hline $\mathrm{PjBL}$ & $1 / 3$ & $1 / 3$ & 1 & 4 & 4 & 6 & 0.15 & 0.07 & 0.13 & 0.28 & 0.28 & 0.18 & 1.09 & 0.18 & $n=6$ \\
\hline SG & $1 / 5$ & $1 / 5$ & $1 / 4$ & 1 & 1 & 7 & 0.09 & 0.04 & 0.03 & 0.07 & 0.07 & 0.21 & 0.51 & 0.09 & $\mathrm{RI}=1.24$ \\
\hline HCM & $1 / 5$ & $1 / 5$ & $1 / 4$ & 1 & 1 & 4 & 0.09 & 0.04 & 0.03 & 0.07 & 0.07 & 0.12 & 0.42 & 0.07 & $\mathrm{CR}=7 \%$ \\
\hline $\mathrm{LC}$ & $1 / 9$ & $1 / 7$ & $1 / 6$ & $1 / 7$ & $1 / 4$ & 1 & 0.05 & 0.03 & 0.02 & 0.01 & 0.02 & 0.03 & 0.16 & 0.03 & \\
\hline Sum & 2.18 & 4.88 & 7.67 & 14.14 & 14.25 & 34.00 & 1.00 & 1.00 & 1.00 & 1.00 & 1.00 & 1.00 & 6.00 & 1.00 & \\
\hline
\end{tabular}

TABLE 19: Overall priority vector and learning strategies ranking.

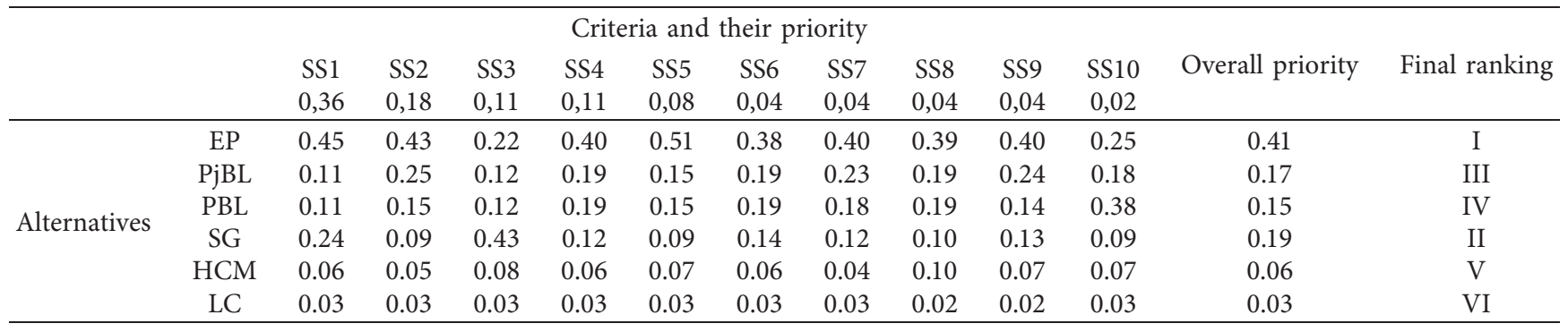




\section{Conclusion}

The importance of this study lies in providing a practical case of a real collaboration between engineering schools and industry in order to reduce the skill gap between learning outcomes and on-the-job requirements. On the one hand, employers are looking for a highly skilled workforce in order to be more attractive and competitive. On the other hand, educational institutions need to improve their students' employability by developing the skills required by the job market. Through the use of the AHP method, we have shown academics and professionals the importance of their collaboration in achieving mutual benefit.

This paper aims to use AHP method to select the best pedagogical method that is able to develop soft skills while respecting the job market requirements. The study is based on a set of criteria that are identified from our previous study, where we have analyzed engineering job ads in order to determine the importance of soft skills in the engineers' employability. The decision problem consists of the comparison of different pedagogical strategies applied in engineering education. The results show that experiential pedagogy (EP) is the optimal solution to answer the market demand with a highest score of $41 \%$. As a result, considerable efforts must be devoted to properly supervise the internships and ensure continuous monitoring and charting of student performance because this learning strategy represents a chance to make the student operational in the market by applying his/her knowledge and abilities in real professional situations.

\section{Data Availability}

The soft skills required by Moroccan employers data used to support the findings of this study have been made available in a previous work online in [23].

\section{Conflicts of Interest}

The authors declare that they have no conflicts of interest.

\section{References}

[1] G. Pinte, "Renverser un cours d'amphithéâtre en première année: quels effets sur l'apprentissage entre pairs pour la génération dite Y?" Bildungsforschung, vol. 1, pp. 1-12, 2017.

[2] A. Giordan, "Éducation thérapeutique du patient: les grands modèles pédagogiques qui les sous-tendent," Médecine des Maladies Métaboliques, vol. 4, no. 3, pp. 305-311, 2010.

[3] L. Dutoit, "Enseignement de type transmissif ou socio-constructiviste?" Doctoral dissertation, Haute École Pédagogique du Canton de Vaud, Lausanne, Switzerland, 2012.

[4] G. Le Boterf, "Des cursus professionnalisants ou par compétences à l'Université: enjeux, craintes et modalités," Actualité de la Formation Permanente, vol. 209, pp. 49-55, 2008.

[5] P. Martin and P. Padula, "Innovation pédagogique à l'université: comparaison entre apprentissage par problèmes et cours traditionnel," Revue Internationale de Pédagogie de L'enseignement Supérieur, vol. 34, pp. 34-43, 2018.
[6] J. E. Mills and D. F. Treagust, "Engineering education-is problem-based or project-based learning the answer," Australasian Journal of Engineering Education, vol. 3, no. 2, pp. 2-16, 2003.

[7] S. Bell, "Project-based learning for the 21st century: skills for the future," The Clearing House: A Journal of Educational Strategies, Issues and Ideas, vol. 83, no. 2, pp. 39-43, 2010.

[8] A. Fayolle and C. Verzat, "Pédagogies actives et entrepreneuriat: quelle place dans nos enseignements?" Revue de l'Entrepreneuriat, vol. 8, no. 2, pp. 1-15, 2009.

[9] J. Larmer, J. Mergendoller, and S. Boss, Setting the Standard for Project Based Learning, ASCD, Alexandria, VA, USA, 2015.

[10] N. Jalinus, R. A. Nabawi, and A. Mardin, "The seven steps of project based learning model to enhance productive competences of vocational students," in Proceedings of the International Conference on Technology and Vocational Teachers (ICTVT), Atlantis Press, Yogyakarta, Indonesia, September 2017.

[11] C. Weyermann, A. Daele, C. Muehlethaler, and R. Voisard, "Une question de temps: apprentissage par problème dans un cours de police scientifique," Revue Internationale de Pédagogie de L'enseignement Supérieur, vol. 31, no. 31, 2015.

[12] K. M. Bonney, "Case study teaching method improves student performance and perceptions of learning gains," Journal of Microbiology \& Biology Education, vol. 16, no. 1, p. 21, 2015.

[13] Y. L. Van Stappen, Enseignement Par la Méthode Des Cas, Joliette: Cégep Joliette-de-Lanaudière, Joliette, Canada, 1989.

[14] M. F. Deschênes, V. Fournier, and A. St-Julien, Le Développement du Jugement en Situation Authentique: L'apprentissage Expérientiel Dans un Contexte de Simulation Pour une Pratique Professionnelle Sécuritaire, Association Québécoise de Pédagogie Collégiale, Montréal, Canada, 2016.

[15] M. Trabon-Natua, La Pédagogie Expérientielle et Ses Effets sur l'apprentissage des Élèves en Milieu Scolaire, Université de Toulouse, Toulouse, France, 2016.

[16] S. Stoloff, C. Spallanzani, and J.-P. Brunelle, "Le cycle de Kolb appliqué à un processus de supervision pédagogique classique: perceptions des supervisés à propos du dispositif d'accompagnement," Approches Inductives, vol. 3, no. 1, pp. 125-156, 2016.

[17] J. Chevrier and B. Charbonneau, "Le savoir-apprendre expérientiel dans le contexte du modèle de David Kolb," Revue des Sciences de L'éducation, vol. 26, no. 2, pp. 287-324, 2000.

[18] P. Lameras, S. Arnab, I. Dunwell, C. Stewart, S. Clarke, and P. Petridis, "Essential features of serious games design in higher education: linking learning attributes to game mechanics," British Journal of Educational Technology, vol. 48, no. 4, pp. 972-994, 2017.

[19] G. Pereira, A. Brisson, R. Prada et al., "Serious games for personal and social learning \& ethics: status and trends," Procedia Computer Science, vol. 15, no. 53, p. 65, 2012.

[20] C. Linehan, S. Lawson, and M. Doughty, "Tabletop prototyping of serious games for "soft skills" training," in Proceedings of the Conference in Games and Virtual Worlds for Serious Applications, pp. 182-185, IEEE, Coventry, UK, 2009.

[21] A. De Gloria, F. Bellotti, and R. Berta, "Serious games for education and training," International Journal of Serious Games, vol. 1, no. 1, 2014.

[22] J. Breuer and G. Bente, "Why so serious? On the relation of serious games and learning," Journal for Computer Game Culture, vol. 4, pp. 7-24, 2010. 
[23] H. Chaibate, A. Hadek, S. Ajana, S. Bakkali, and K. Faraj, "Analyzing the engineering soft skills required by Moroccan job market," in Proceedings of the 5th International Conference on Optimization and Applications (ICOA) IEEE, pp. 1-6, Kenitra, Morocco, 2019.

[24] H. Chaibate and S. Bakkali, "Skills for employability: identification of the Soft Skills required in engineering education," The Journal of Quality in Education, vol. 7, no. 9, 2017.

[25] D. Sabaei, J. Erkoyuncu, and R. Roy, "A review of multicriteria decision making methods for enhanced maintenance delivery," Procedia CIRP, vol. 37, pp. 30-35, 2015.

[26] J. Si, L. Marjanovic-Halburd, F. Nasiri, and S. Bell, "Assessment of building-integrated green technologies: a review and case study on applications of Multi-Criteria Decision Making (MCDM) method," Sustainable Cities and Society, vol. 27, pp. 106-115, 2016.

[27] T. L. Saaty and D. Ergu, "When is a decision-making method trustworthy? Criteria for evaluating multi-criteria decisionmaking methods," International Journal of Information Technology \& Decision Making, vol. 14, no. 6, pp. 1171-1187, 2015.

[28] R. E. Hodgett, "Comparison of multi-criteria decision-making methods for equipment selection," The International Journal of Advanced Manufacturing Technology, vol. 85, no. 5-8, pp. 1145-1157, 2016.

[29] R. K. Gavade, "Multi-Criteria Decision Making: an overview of different selection problems and methods," International Journal of Computer Science and Information Technologies, vol. 5, no. 4, pp. 5643-5646, 2014.

[30] M. Agrebi, "Méthodes d'aide à la décision multi-attribut et multi-acteur pour résoudre le problème de sélection dans un environnement certain/incertain: cas de la localisation des centres de distribution," Doctoral dissertation, Université de Valenciennes et du Hainaut-Cambresis, Valenciennes, France, 2018.

[31] M. Aruldoss, T. M. Lakshmi, and V. P. Venkatesan, "A survey on multi criteria decision making methods and its applications," American Journal of Information Systems, vol. 1, no. 1, pp. 31-43, 2013.

[32] T. Azdast, R. E. Lee, R. Hasanzadeh, M. Moradian, and S. M. Shishavan, "Investigation of mechanical and morphological properties of acrylonitrile butadiene styrene nanocomposite foams from analytical hierarchy process point of view," Polymer Bulletin, vol. 76, no. 5, pp. 2579-2599, 2019.

[33] S. Mahmudova and Z. Jabrailova, "Development of an algorithm using the AHP method for selecting software according to its functionality," Soft Computing, vol. 24, no. 11, pp. 8495-8502, 2020.

[34] L. Jurík, N. Horňáková, E. Šantavá, D. Cagáňová, and J. Sablik, "Application of AHP method for project selection in the context of sustainable development," Wireless Network, vol. 8, pp. 1-10, 2020.

[35] R. D. F. S. M. Russo and R. Camanho, "Criteria in AHP: a systematic review of literature," Procedia Computer Science, vol. 55, pp. 1123-1132, 2015.

[36] M. Meng, "The research and application of the risk evaluation and management of information security based on AHP method and PDCA method,"vol. 3, pp. 379-383, in Proceedings of the 6th International Conference on Information Management, Innovation Management and Industrial Engineering, vol. 3, , IEEE, Xi'an, China, November 2013.

[37] B. Jovanović, J. Filipović, and V. Bakić, "Prioritization of manufacturing sectors in Serbia for energy management
improvement-AHP method," Energy Conversion and Management, vol. 98, pp. 225-235, 2015.

[38] S. Kumar, N. Parashar, and A. Haleem, "Analytical hierarchy process applied to vendor selection problem: small scale, medium scale and large scale industries," Business Intelligence Journal, vol. 2, no. 2, pp. 355-362, 2009.

[39] V. T. Lokare and P. M. Jadhav, "Using the AHP and TOPSIS methods for decision making in best course selection after HSC," in Proceedings of the International Conference on Computer Communication and Informatics (ICCCI), pp. 1-6, IEEE, Coimbatore, India, January 2016. 